\title{
AN ATTEMPT TO EVALUATE THE ECONOMY OF UPPER SILESIA \\ BY OWNERSHIP SECTORS BASED ON THE ECONOMETRIC MODEL \\ AND THE FINAL EQUATION
}

Józef Biolik, Prof.

Department of Econometrics

Faculty of Management

University of Economics in Katowice

1 Maja 50, 40-287 Katowice

e-mail:jozef.biolik@ue.katowice.pl

Received 14 September 2011, Accepted 29 December 2011

\begin{abstract}
The paper attempts to use the econometric model in the evaluation of trends in the economy of the Śląskie Voivodeship. The analysis is mainly based on the final equation of the model. The characteristic roots indicate that the economy of Upper Silesia does not have a cyclical nature (the lack of complex roots) and the private enterprise sector is characterised with higher efficiency than the public enterprise sector, since the curve for endogenous variable $y_{t}$ is converging with the asymptote $y=0$ more quickly in the case of public enterprises than in the case of private enterprise sector.
\end{abstract}

Keywords: econometric model, final equation, the roots of the final equation, public and private enterprise sector.

JEL classification: C51, C52. 


\section{Introduction}

The econometric model of an economic enterprise is one of the tools used for the analysis and evaluation of economic processes. The study is an attempt to evaluate the construction, estimation and analysis of the dynamic properties of a mini-model of the economy of the Sląskie Voivodeship by ownership sectors. It aims to verify the hypothesis that the growth dynamics in the sector of public enterprises differs from growth dynamics in the sector of private enterprises. The dynamic properties of the model are analysed using the final equations of selected variables. The mechanism for developing the final equation of a variable is based on the elimination through consecutive substituting of all other unlagged and lagged endogenous variables in a given equation. As a result, we obtain an equation which features only a researched endogenous variable and its subsequent lags and unlagged and lagged exogenous variables. Formally speaking, due to $y_{i t}$, the final equation is a difference equation. The analysis of the solution to this equation allows for drawing conclusions on the proper motions (an independent trend) and stability of the system. The system will be stable when the impact of lagged endogenous variables on variable $y_{i t}$ will be expiring in nature, which means that the trajectory of proper motion will strive to reach equilibrium.

\section{The model of relationships between variables characterising the economy of the Śląskie Voivodeship}

The estimation and analysis were based on annual data ${ }^{1}$ regarding variables characterising the selected aspects of the economy of the Śląskie Voivodeship in the years 1999-2009. We specified and estimated two types of models in the enterprise sector due to ownership form:

- the model of relationships between variables characterising the economy of the Śląskie Voivodeship in the public enterprise sector,

- the model of relationships between variables characterising the economy of the Śląskie Voivodeship in the private enterprise sector.

In order to make a comparative analysis based on ownership form, we use the same categories of variables in the models. The econometric analysis uses the values published in the Statistical Bulletins of the Śląskie Voivodeship ${ }^{1}$ and they were marked in the following way:

PZSPU $_{t}$ - average paid employment in enterprise sector, public sector, in thousands people, 
PZSPR $_{\mathrm{t}}$ - average paid employment in enterprise sector, private sector, in thousands people,

PWBPU $_{t}$ - average gross wages and salaries in public enterprise sector, in PLN,

$\mathrm{PWBPR}_{\mathrm{t}}$ - average gross wages and salaries in private enterprise sector, in PLN,

PSPPU $_{t}$ - sold production of industry, public sector, in PLN million,

$\operatorname{PSPPR}_{\mathrm{t}}$ - sold production of industry, private sector in PLN million,

$\mathrm{PCDPU}_{\mathrm{t}}$ - revenues from total activity of enterprises, public sector, in PLN million,

$\mathrm{PCDPR}_{\mathrm{t}}$ - revenues from total activity of enterprises, private sector, in PLN million,

$\mathrm{KUPPU}_{\mathrm{t}}-$ costs of obtaining revenues from total activity, public sector, in PLN million,

$\mathrm{KUPPR}_{\mathrm{t}}$ - costs of obtaining revenues from total activity, private sector in PLN million,

WFNPU $_{t}-$ net financial result in public enterprise sector, in PLN million,

$\mathrm{WFNPR}_{\mathrm{t}}-$ net financial result in private enterprise sector, in PLN million,

$\mathrm{NISPU}_{t}$ - investment outlays, public sector, in PLN million,

$\mathrm{NISPR}_{\mathrm{t}} \quad$ - investment outlays, private sector, in PLN million.

The relationships between variables are presented in this scheme:

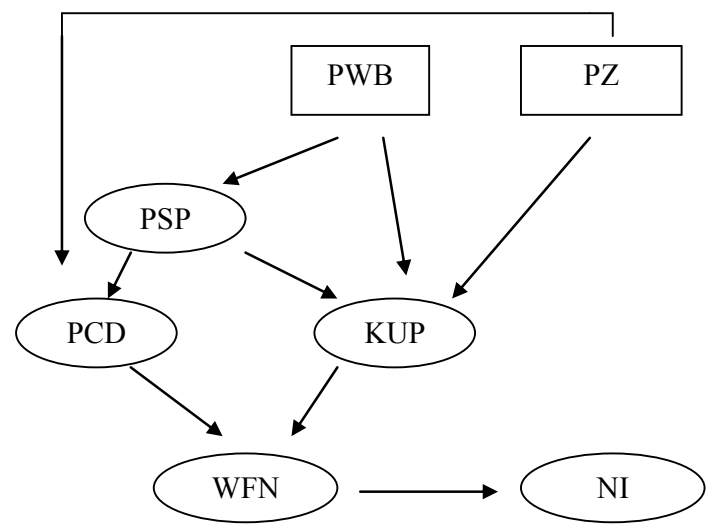

Fig. 1. The scheme of relationships between variables characterising the economy of the Śląskie Voivodeship

Source: own study.

In order to make a comparative analysis based on ownership form, we use the same categories of variables in the models. 
The scheme of relationships between variables shows that this model is recursive and dynamic, as it includes lagged endogenous variables. The exogenous variables of the model are average paid employment in enterprises and average gross wages and salaries.

The results of the estimation of the model of relationships between variables characterizing the economy of the Śląskie Voivodeship in the public enterprise sector:

- The equation of sold production of industry in the public enterprise sector:

$$
\begin{gathered}
P S P P U_{t}=0.3956 P_{P P P U_{t-1}}+89.9621 P Z S P U_{t}+3.8633 P^{2} W B P U_{t}-14162.3745 \\
R^{2}=0.75 ; D-W=2.56
\end{gathered}
$$

- The equation of revenues from total activity:

$$
\begin{gathered}
P C D P U_{t}=-0.1831 P C D P U_{t-1}+1.4305 P S P P U_{t}+55.8736 P_{P S P U}+759.6728 \\
R^{2}=0.923 ; D-W=2.81,
\end{gathered}
$$

- The equation of costs of obtaining revenues:

$$
\begin{gathered}
\text { KUPPU }_{t}=-0.0598 \text { KUPPU }_{t-1}+0.5917 P_{P P P U_{t}}+197.6487 P \mathrm{PSPU}_{t}+ \\
+5.8877 P W B P U_{t}-32400.940 \\
R^{2}=0.93 ; D-W=1.38
\end{gathered}
$$

- The equation of the total net financial result:

$$
\begin{aligned}
& \text { WFNPU }_{t}=0.0133 \text { WFNPU }_{t-1}+0.8504 P_{C D P U}-0.8532 \mathrm{KUPPU}_{t}-95.3974 \\
& R^{2}=0.99 ; D-W=1.38,
\end{aligned}
$$

- The equation of total investment outlays:

$$
\begin{gathered}
N I P U_{t}=1.0095 N I P U_{t-1}+0.1047 \text { WFNPU }_{t}+25.2009 \\
R^{2}=0.80 ; D-W=1.12 .
\end{gathered}
$$

The results of the estimation of the model of relationships between variables characterizing the economy of the Śląskie Voivodeship in the private enterprise sector:

- The equation of sold production of industry in the private enterprise sector:

$$
\begin{gathered}
P S P P R_{t}=0.4044 P S P P R_{t-1}-181.9157 P Z S P R_{t}+51.3089 P W B P R_{t}+26537.9872 \\
R^{2}=0.96 ; D-W=2.56,
\end{gathered}
$$

- The equation of revenues from total activity in the private enterprise sector:

$$
\begin{gathered}
P C D P R_{t}=0.1139 P C D P R_{t-1}+1.2180 P S P P R_{t}+54.2245 P Z S P R_{t}-17692.9027 \\
R^{2}=0.99 ; D-W=1.87,
\end{gathered}
$$


- The equation of costs of obtaining revenues:

$$
\begin{gathered}
K U P P R_{t}=0.1981 K_{U P P R_{t-1}}+0.9338 P S P P R_{t}+36.4274 P Z S P R_{t}+ \\
+8.3156 P W B P R_{t}-18293.6130 \\
R^{2}=0.99 ; D-W=1.77
\end{gathered}
$$

- The equation of the total net financial result:

$$
\begin{gathered}
W F N P R_{t}=-0.0658 W_{W N P R_{t-1}}+0.8715 P C D P R_{t}-0.8642 K U P P R_{t}-944.5454 \\
R^{2}=0.99 ; D-W=2.16
\end{gathered}
$$

- The equation of total investment outlays:

$$
\begin{gathered}
N I P R_{t}=0.5166 N_{N I P R_{t-1}}+0.3236 W_{F N P R_{t}}+1301.1485 \\
R^{2}=0.90 ; D-W=1.80 .
\end{gathered}
$$

All the equations of particular types of models are characterised with high conformity, measured by the coefficient of determination, the lowest value of which is 0.8037 and applies to the equation on investment outlays in the public enterprise sector.

\section{The construction of the final equations of the models}

If endogenous variables have only one-period lags in a $\mathrm{G}$ equation econometric model, due to the selected endogenous variable the final equation of the model is as follows ${ }^{3}$ :

$$
y_{t}+\alpha_{1} y_{t-1}+\alpha_{2} y_{t-2}+\ldots .+\alpha_{G} y_{t-G}=L\left(X_{1}, X_{2}, \ldots, X_{k}\right)
$$

where: $L\left(X_{1}, X_{2}, \ldots, X_{k}\right)$ is a linear function of exogenous variables of the model.

The presentation of the dependence of $y_{t}$ on $t$ as an explicit formula of a certain function $y=F(t)$ is obtained as the sum of the general solution to the homogeneous equation and the particular solution to the nonhomogeneous equation. The homogeneous equation is expressed as:

$$
y_{t}+\alpha_{1} y_{t-1}+\alpha_{2} y_{t-2}+\ldots .+\alpha_{G} y_{t-G}=0
$$

and its general solution is dependent on $\mathrm{G}$ initial conditions and on the roots of the characteristic equation:

$$
\lambda^{G}+\alpha_{1} \lambda^{G-1}+\ldots+\alpha_{G}=0
$$

Since the general solution to the homogeneous equation expresses the mechanism of proper motions of the system, the analysis of the homogeneous equation and the resultant characteristic equation informs on the nature of proper fluctuations, in particular an independent trend and possible periodic fluctuations. 
In the case of real and single roots of the characteristic equation, the general solution to the homogeneous equation is expressed as ${ }^{4}$ :

$$
y_{t}=\sum_{j=1}^{G} A_{j} \lambda_{j}^{t}
$$

where:

$\lambda_{j}-$ is the $j$-th characteristic root,

$A_{j}-$ is the $j$-th initial condition.

In this situation, the proper motion of the system does not include periodic fluctuations, whereas in the case when $\left|\lambda_{j}\right|<.1$ the curve of motion is an asymptotic downward curve towards the axis $y=0$ (when $t \rightarrow \infty)$.

Whereas, in turn, the solution to the characteristic equation is $r$ real roots and $2 \mathrm{~s}$ complex roots $\left(\lambda_{j}=a_{j} \pm i b_{j}\right)$, the solution can be expressed as follows:

$$
y_{t}=\sum_{j=1}^{r} A_{j} \lambda_{j}^{t}+\sum_{j=r+1}^{r+s} A_{j} \rho_{j}^{t} \cos \left(\frac{2 \pi t}{\Theta_{j}}+\delta_{j}\right)
$$

where:

$\Theta=\operatorname{arctg} \frac{b_{j}}{a_{j}}-$ defines the length of periodic fluctuations,

$\begin{aligned} \rho_{\mathrm{j}}=\sqrt{a_{j}^{2}+b_{j}^{2}}- & \text { defines the changes in the amplitudes of fluctuations compared to the } \\ & \text { initial amplitude, }\end{aligned}$

$\delta_{\mathrm{j}}$ - is determined based on the initial conditions defining for what value $\mathrm{t}$ the $j$-th periodic component has the maximum value.

Based on the results of the estimation of the structural form of the econometric model, the homogeneous equations and the corresponding characteristic equations can be developed.

In the public enterprise sector:

- The homogeneous equation for the variable $P S P P U_{t}$ is expressed as:

$$
P S P P U_{t}-0.3956 P S P P U_{t-1}=0,
$$

and the characteristic equation $\lambda-0,3956=0$, so the characteristic root equals $\lambda=0,3956$.

- The homogeneous equation for the variable $P C D P U_{t}$ is expressed as:

$$
P C D P U_{t}-(0.3956-0.1831) P C D P U_{t-1}+[0.3956(-0.1831)] P C D P U_{t-2}=0,
$$


The characteristic equation: $\lambda^{2}-0.2125 \lambda-0.07243436=0$ has two characteristic roots, which are real numbers $\lambda_{1}=-0.3662$ and $\lambda_{2}=0.3956$.

- The homogeneous equation for the variable $\mathrm{KUPPU}_{\mathrm{t}}$ is expressed as:

$$
K U P P U_{t}-(0.3956-0.0598) K U P P U_{t-1}+[0.3956(-0.0598)] K U P P U_{t-2}=0 .
$$

The characteristic equation: $\lambda^{2}-0.3358 \lambda-0.02365688=0$ has two characteristic roots, which are real numbers: $\lambda_{1}=-0.0598$ and $\lambda_{2}=0.3956$.

In the private enterprise sector:

- The homogeneous equation for the variable $P S P P R_{t}$ is expressed as:

$$
P S P P R_{t}-0.4044 P S P P R_{t-1}=0,
$$

and the characteristic equation $\lambda-0.4044=0$; accordingly, the characteristic root equals $\lambda=0.4044$.

- The homogeneous equation for the variable $\mathrm{PCDPR}_{\mathrm{t}}$ is expressed as:

$$
P C D P R_{t}-(0.4044+0.1139) P C D P R_{t-1}+0.4044 \cdot 0.1139 P C D P R_{t-2}=0,
$$

The characteristic equation: $\lambda^{2}-0.5183 \lambda+0.04606116=0$ has two characteristic roots, which are real numbers: $\lambda_{1}=0.1139$ and $\lambda_{2}=0.4044$.

- The homogeneous equation for the variable $\mathrm{KUPPR}_{\mathrm{t}}$ is expressed as:

$$
K U P P R_{t}-(0.4044+0.1981) K U P P R_{t-1}+(0.4044 \cdot 0.1981) K U P P R_{t-2}=0 .
$$

The characteristic equation: $\lambda^{2}-0.6025 \lambda+0.08011164=0$ has two characteristic roots, which are real numbers: $\lambda_{1}=0.2031$ and $\lambda_{2}=0.4044$.

The characteristic roots that we achieved fulfil the condition $|\lambda|<1$ in every system, which proves its stability. Moreover, in each equation of the same system we have the same value of the characteristic $\operatorname{root}^{5}$ :

- for the public enterprise sector $-\lambda=0.3956$,

- for the private enterprise sector $-\lambda=0.4044$.

The analysis of the characteristic roots shows that the only characteristic roots are the roots that are real numbers. The lack of complex roots may prove the lack of cyclical nature of the economy of the Śląskie Voivodeship in the analysed period of time.

If we substitute the values of the respective characteristic roots in formula (4), we can see that in the case of the private sector the values of endogenous variables converge with the asymptote $y=0$ more quickly, (with no external incentives) due to lower values of $\lambda_{\mathrm{j}}$. The values of coefficients for the public and private enterprise sectors ae presented in Figures 2 and 3. 
Table 1. The comparison of the characteristic roots of the final equation of particular variables by ownership sectors

\begin{tabular}{|l|c|c|}
\hline \multirow{2}{*}{ Endogenous variables } & \multicolumn{2}{c|}{ Ownership sector } \\
\cline { 2 - 3 } & Public & Private \\
\hline Sold production of industry & 0.3956 & 0.4044 \\
\hline \multirow{2}{*}{ Revenues from total activity } & 0.3956 & 0.4044 \\
& -0.3662 & 0.1139 \\
\hline \multirow{2}{*}{ Costs of obtaining revenues from total activity } & 0.3956 & 0.4044 \\
& -0.0598 & 0.2031 \\
\hline
\end{tabular}

Source: own calculations.

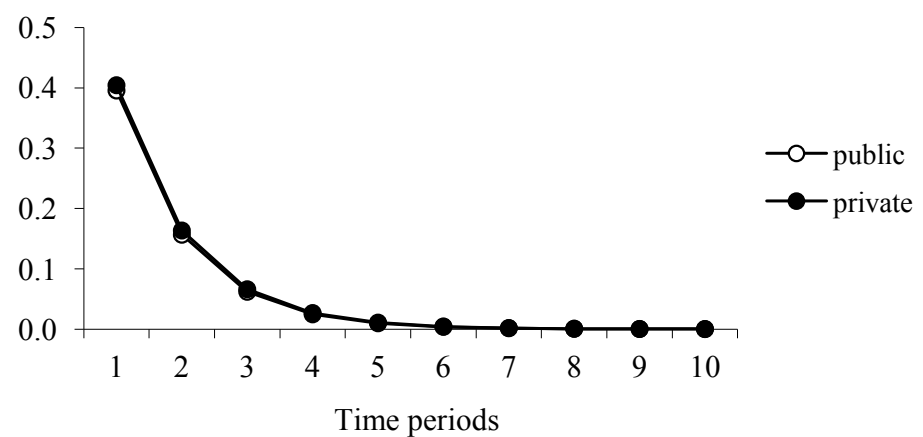

Fig. 2. The values of coefficients of sold production of industry for the public and private sectors (the values of coefficients $\lambda^{t}$ in particular time periods)

Source: own study.

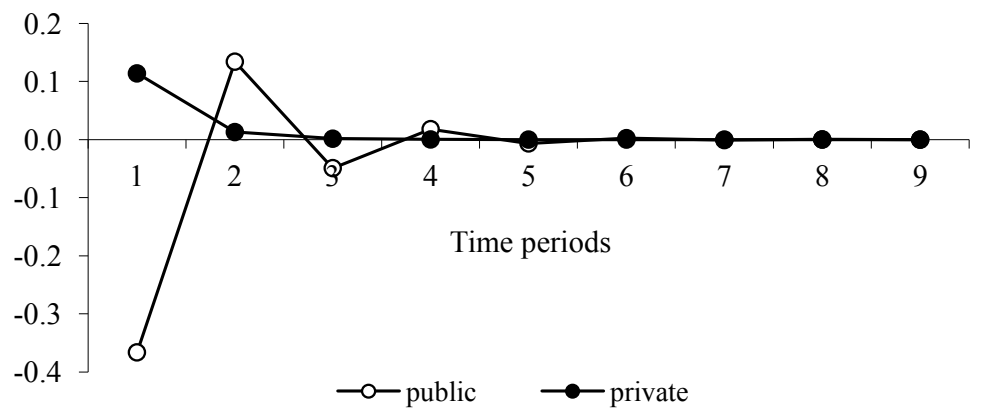

Fig. 3. The values of coefficients of revenues from total activity by ownership sectors (the values of coefficients $\lambda^{t}$ in particular time periods)

Source: own study. 


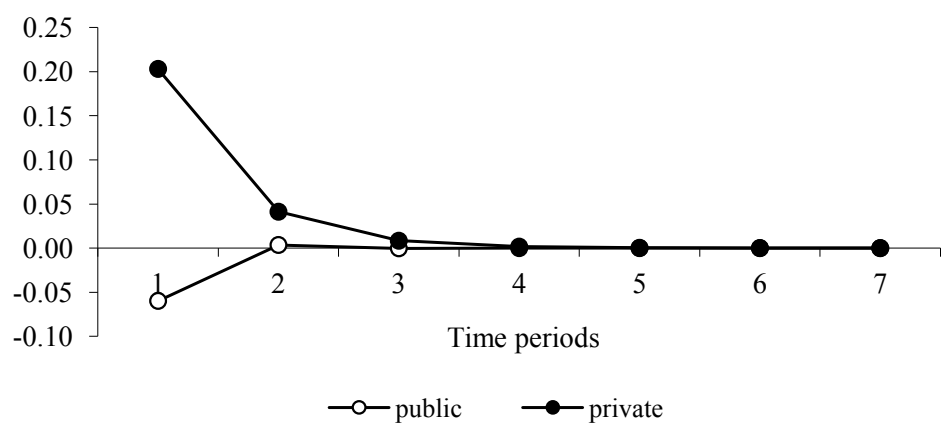

Fig. 4. The values of coefficients of costs of obtaining revenues for the public and private sectors (the values of coefficients $\lambda^{t}$ in particular time periods)

Source: own study.

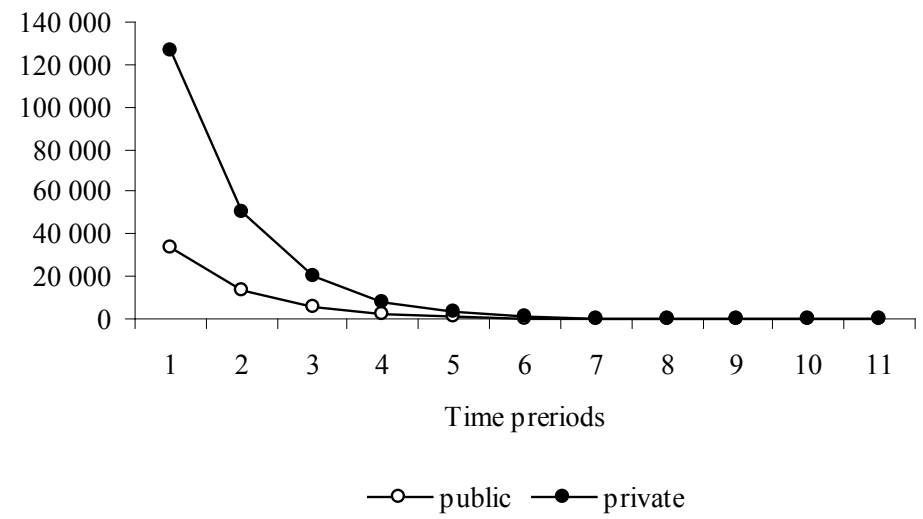

Fig. 5. Independent trends in sold production of industry by ownership sectors $P S P_{t}=P S P_{0} \lambda^{t}$ Source: own study.

For the variables "Revenues from total activity" and "Costs of obtaining revenues from total activity" in the public sector, the oscillation occurs from both sides due to the negative values of the latter characteristic root.

\section{Conclusions}

The results of the estimation of the equations characterising the economy of the Sląskie Voivodeship both in the public and private sectors show high conformity, the higher one for the private enterprise sector. 
The final equations, determined based on estimated equations, and the characteristic equations corresponding with particular variables and ownership sectors have the characteristic roots that are real numbers the value of which is $|\lambda|<1$. This leads to the conclusion that the economy of the Śląskie Voivodeship did not show the tendency towards cyclical fluctuations in the analysed period of time, the system is stable, and in the case of the lack of external incentives over a longer period of time the economic system will be striving towards 0 both in the public and private sectors, with the public sector converging towards zero more quickly.

\section{Notes}

1 Due to short time series, analyses presented in Biolik (2007), pp. 27-43, Biolik (2008a), pp. 45-55, Biolik (2008b), pp. 11-30, Biolik (2009), pp. 49-56, Biolik (2010), pp. 31-41 were based on quarterly data, which showed certain deficiencies.

2 See Statistical Bulletins of the Śląskie Voivodeship.

3 See Pawłowski (1981).

4 See ibidem, p. 42.

5 This is the property of the characteristic roots of the final equation, because particular endogenous variables are affected by the same developmental mechanisms.

\section{References}

Biolik, J. (2007). Analiza porównawcza sektora przedsiębiorstw publicznych i prywatnych województwa ślaskiego $z$ wykorzystaniem mnożników dynamicznych i calkowitych. In: Modelowanie i prognozowanie gospodarki narodowej. Prace i Materiały Wydziału Zarządzania Uniwersytetu Gdańskiego 5/2007, Sopot.

Biolik, J. (2008a). Dynamiczne wtasności modelu gospodarki województwa śląskiego na podstawie równania końcowego. In: Zarzadzanie - współczesne problemy badawcze, ed. A. Bajdak and W. Czakon. Katowice: Wydawnictwo Akademii Ekonomicznej im. K. Adamieckiego w Katowicach.

Biolik, J. (2008b). Analiza mnożnikowa na podstawie modelu ekonometrycznego wybranych aspektów gospodarki województwa ślaskiego. In: Rozwój gospodarczy województwa śląskiego na tle gospodarki Polski, part II, ed. A.S. Barczak. Prace Naukowe Akademii Ekonomicznej im. K. Adamieckiego w Katowicach.

Biolik, J. (2009). Dynamiczne własności modelu gospodarki województwa ślaskiego na podstawie równania końcowego. In: Zmiany struktury zjawisk społeczno-gospodarczych na 
górnym Śląsku, part I, ed. A.S. Barczak. Prace Naukowe Akademii Ekonomicznej im. K. Adamieckiego w Katowicach.

Biolik, J. (2010). Dynamiczne własności modelu gospodarki województwa śląskiego i modelu gospodarki Polski na podstawie równania końcowego. In: Dynamika zjawisk społecznogospodarczych na górnym Śląsku, ed. A.S. Barczak. Prace Naukowe Akademii Ekonomicznej im. K. Adamieckiego w Katowicach.

Pawłowski, Z. (1981). Elementy ekonometrii, Warszawa: Wydawnictwo Naukowe PWN.

Biuletyny Statystyczne Województwa Śląskiego 1999-2010. 